UDC 622.245

\title{
Self-healing cements - the key to maintaining the integrity of cement sheath. Part 1
}

\author{
Authors: \\ Farit A. Agzamov, \\ Professor of the Department «Oil and Gas Well Drilling», Ufa State Petroleum Technological University, \\ Ufa, Bashkortostan Republic, Russia, faritag@yandex.ru; \\ Elvira R. Ismagilova, \\ MSc (UK, University of Salford), PhD student of the Department «Oil and Gas Well Drilling», \\ Ufa State Petroleum Technological University, Ufa, Bashkortostan Republic, Russia, \\ yusupova_elvira@mail.ru
}

Abstract: To control water production, it is necessary to seal the channels of 20-25 mm thickness in the cement sheath at a depth of hundreds and thousands of meters. The most promising solution is the use of self-healing cements.

The concept of self-healing materials has been known since the 1980s due to the studies of Donald Jud. The most fundamental works are by Sybrand van der Zwaag, Sheba D. Bergman and Fred Wudl, Richard P. Wool, D.Y Wu, N.R. Sottos, Erin B. Murphy, Henk Jonkers, who substantiated the concept, suggested technologies and additives to restore the integrity of polymer and cement materials.

Despite active research in this area, Schlumberger is the only service company which elaborated and successfully applied the «self-healing» well cement called Futur.

The authors of the article set the task of well cement modification that enables autonomous «healing» of water-conducting channels through which formation water migrates.

The following materials were used in the study: polyacrylamide (PAA), water-swellable polymer (VNP V-615), sodium polyacrylate (SP), cross-linked PAA copolymers, active waterproofing mineral additives and swelling elastomers. Most of the additives have a degree of swelling of more than $150 \%$, they effectively reduce a permeability of the cement stone, however multi-layer coating is required to control the speed of their swelling. A significant drawback of the analyzed materials was the complexity of the coating.

A cross-linked AA copolymer based on anionic polycrylamide was the most effective reagent, which was easy to cover with a water-soluble shell. The cement stone with integrated agent of AA copolymer demonstrated a permeability of $0.0018 \mu \mathrm{m}^{2}$ with the strength of the samples for bending at the age of 2 days equal to $8.0 \mathrm{MPa}$.

Keywords: cement stone, water passages, water absorbing reagents, modifying additives, triggering mechanism, autonomous cement sheath repair, self-healing cements.

For citation: Agzamov F.A., Ismagilova E.R. Self-healing cements - the key to maintaining the integrity of cement sheath. Part 1. Nanotehnologii v stroitel'stve = Nanotechnologies in Construction. 2019, Vol. 11, no. 5, pp. 577-586. DOI: 10.15828/2075-85452019-11-5-577-586.

Machine-readable information on CC-licenses (HTML-code) in metadata of the paper

$<$ a rel="license" href="http://creativecommons.org/licenses/by/4.0/"><img alt="Creative Commons License" style="border-width:0" src="https://i.creativecommons. org///by/4.0/88x31.png" / $></ \mathrm{a}><$ br $/><$ span xmlns:dct="http://purl.org/dc/terms/" href="http://purl.org/dc/dcmitype/Text" property="dct:title" rel="dct:type" $>$ Selfhealing cements - the key to maintaining the integrity of cement sheath. Part 1.</span $>$ by $<$ a xmlns:cc="http://creativecommons.org/ns\#" href="Nanotehnologii $v$ stroitel'stve = Nanotechnologies in Construction. 2019, Vol. 11, no. 5, pp. 577-586. DOI: 10.15828/2075-8545-2019-11-5-577-586" property="cc:attributionName" rel="cc:attributionURL" $>$ Agzamov F.A., Ismagilova E.R. $</$ a $>$ is licensed under a $<$ a rel="license" href="http://creativecommons.org/licenses/by/4.0/" $>$ Creative Commons Attribution 4.0 International License $</ \mathrm{a}>$. $<\mathrm{br} />$ Based on a work at $<$ a xmlns:dct="http://purl.org/dc/terms/" href="http://nanobuild.ru/en EN/nanobuild-5-2019/" rel="dct:source" >http://nanobuild.ru/en_EN/nanobuild-5-2019/</a $>$.<br $/>$ Permissions beyond the scope of this license may be available at $<$ a xmlns:cc="http://creativecommons.org/ns\#" href="faritag@yandex.ru" rel="cc:morePermissions" $>$ faritag@yandex.ru</a $>$.

The paper has been received by editors: 28.08.2019.

The paper has been received by editors after peer-review: 20.09.2019.

The paper has been accepted for publication: 29.09.2019. 


\title{
Самозалечивающиеся цементы - ключ к сохранению герметичности крепи скважин. Часть 1
}

\author{
Авторы: \\ Агзамов Фарит Акрамович, \\ профессор кафедры «Бурение нефтяных и газовых скважин» ФГБОУ ВО «УГНТУ»; \\ г. Уфа, Россия, faritag@yandex.ru; \\ Исмагилова Эльвира Римовна, \\ магистр нефтегазового дела (Великобритания, Университет Сэлфорда), \\ аспирант кафедры «Бурение нефтяных и газовых скважин» ФГБОУ ВО «УГНТУ»; г. Уфа, Россия, \\ yusupova_elvira@mail.ru
}

Резюме: Для ограничения водопритока в скважинах необходимо герметизировать каналы в цементном кольце толщиной 20-25 мм, на глубине сотен и тысяч метров. При этом наиболее перспективным решением является применение самозалечивающихся цементов.

Работы по получению самовосстанавливающихся материалов начались с 1980-х годов, с работ Дональда Джуда. Широкую известность получили работы Сибрандван дер Цваага, Шеба Д. Бергмана и Фреда Вудла, Ричарда П. Вула, Д.И. Ву, Н.Р. Соттоса, Эрина Б. Мерфи, Хенка Джонкерса, которые обосновали концепции, предложили технологии и добавки для восстановления герметичности полимерных и цементных материалов. Несмотря на активное развитие этого направления исследований, только компания Шлюмберже остается единственной, разработавшей и успешно применяющей для цементирования скважин «самозалечивающийся» цемент «Futur».

Авторами статьи ставилась задача модифицирования тампонажных цементов, способных к автономному «залечиванию» водопроводящих каналов притока пластовой воды.

В исследованиях использованы полиакриламид (ПАА), водонабухающий полимер (ВНП В-615), полиакрилат натрия (ПАН), сшитые сополимеры ПАА, активные гидроизолирующие минеральные добавки и набухающие эластомеры. Большинство добавок имеет степень набухания более 150\%, они эффективно снижают проницаемость цементного камня, но для регулирования скорости их набухания необходимы многослойные оболочки, создание которых является существенным недостатком большинства материалов.

Наиболее эффективным реагентом явился сшитый сополимер АА на основе анионного поликриламида, легко покрывающийся водорастворимой оболочкой. Цементный камень с добавкой сополимера АА имел проницаемость 0,0018 мкм ${ }^{2}$ при прочности на изгиб в возрасте 2-х суток 8,0 МПа.

Ключевые слова: цементный камень, водопроводящие каналы, самовосстанавливающиеся материалы, триггерный механизм, автономное самовосстановление цементного камня.

Для цитирования: Агзамов Ф.А., Исмагилова Э.Р., Самозалечивающиеся цементы - ключ к сохранению герметичности крепи скважин. Часть 1 // Нанотехнологии в строительстве. - 2019. - Том 11, № 5. - С. 577-586. - DOI: 10.15828/2075-85452019-11-5-577-586.

Машиночитаемая информация о СС-лицензиях (HTML-код) в метаданных статьи

$<$ a rel="license" href="http://creativecommons.org/licenses/by/4.0/"><img alt="Creative Commons License" style="border-width:0" src="https://i.creativecommons. org///by/4.0/88x31.png" / $></$ a $><$ br / $><$ span xmlns:dct="http://purl.org/dc/terms/" href="http://purl.org/dc/dcmitype/Text" property="dct:title" rel="dct:type" $>$ Selfhealing cements - the key to maintaining the integrity of cement sheath. Part 1.</span $>$ by $<$ a xmlns:cc="http://creativecommons.org/ns\#" href="Nanotehnologii v stroitel'stve = Nanotechnologies in Construction. 2019, Vol. 11, no. 5, pp. 577-586. DOI: 10.15828/2075-8545-2019-11-5-577-586" property="cc:attributionName" rel="cc:attributionURL" $>$ Agzamov F.A., Ismagilova E.R. $</$ a $>$ is licensed under a $<$ a rel="license" href="http://creativecommons.org/licenses/by/4.0/" $>$ Creative Commons Attribution 4.0 International License $</ \mathrm{a}>$. $<\mathrm{br} />$ Based on a work at $<$ a xmlns:dct="http://purl.org/dc/terms/" href="http://nanobuild.ru/en EN/nanobuild-5-2019/" rel="dct:source" $>$ http://nanobuild.ru/en_EN/nanobuild-5-2019/</a $>$.<br $/>$ Permissions beyond the scope of this license may be available at $<$ a xmlns:cc="http://creativecommons.org/ns\#" href="faritag@yandex.ru" rel="cc:morePermissions" $>$ faritag@yandex.ru</a $>$.

Статья поступила в редакцию: 28.08.2019.

Статья поступила в редакцию после рецензирования: 20.09.2019.

Статья принята к публикации: 29.09.2019. 


\section{INTRODUCTION}

$\mathrm{T}$ he history of uneven-aged wells operation reveals the vulnerability of cement stone while being exposed to high dynamic loads and inner pressures as well as to aggressive formation water seepage [1]. However, there is a possibility to maintain the integrity of well lining as long as an appropriate modification of well cement is chosen. Many Russian and foreign scientists set the task of well cement modification using special additives which can effectively seal the space between the borehole wall and the casing, as well as eliminate channeling thus preventing the formation of a system of cracks and behind-the-casing leaks. The most promising solution of the channel mending is the use of self-healing cements.

\section{MAIN PART}

\section{Historical review}

The concept of self-healing polymeric materials has been known since the 1980s. In 1981 Donald Jud featured a possibility of healing stealth micro-cracks for prolongation the service life of the polymeric components [2].

The first articles, which further inspired scientists of the entire world, were «Passive smart self-repair in polymer matrix composite materials» published in Virginia, USA [3] and «Autonomic healing of polymer composites» [4], which demonstrated successful attempts to assess regularity of crack prolongation within polymeric materials and the ability of range of polymeric materials to repair the crack. In 2003 a group of researchers from different American universities demonstrated a self-healing fiber-reinforced structural polymer, which was a matrix composite material with microencapsulated chemical catalyst and was exposed to the crack propagation and room temperature [5]. Since that time, a period of interest in self-healing mechanism and materials searching had risen, attracted different organizations from architecture, civil engineering to US air force [6] and European Space Agency [7], which largely invested in self-healing polymers studies.

The first overview of wide spectrum of self-healing materials was written by professor of Deft University of Technologies Dr. Sybrand van der Zwaag, who described categories, different design approaches and factual structural abilities of such materials as ceramics, polymers and metals [8]. The confident self-healing studies of Deft University provided to the university holding the First International Conference on Self-healing Materials in the Netherlands, 2007. At the same time a group of American researchers developed a concept of effective size encapsulating of self-healing polymers, comparing to a possible max size of crack thus carried out the desirable response of healing effect to damage [9].
In the journal of Materials Chemistry issued in 2008, Dr. Sheba D. Bergman and Professor Fred Wudl, based on the property of reversibility they fully described the mend ability of polymers [10]. The same results were confirmed and supplemented by the research group of the University of Warwick, which proceeded the study of intrinsic healing in polymers in more details [11]. Professor Richard P. Wool contributed into the material science described mechanical and thermally induced damage and healing for polymers, based on the related area of polymer-polymer interfaces [12]. The team of D.Y. Wu, in their article described the fracture mechanism and concept of healing in polymeric systems, also proposed methods for evaluating self-healing efficiencies [13]. The full spectrum of self-healing applications was summed up in the papers of Chinese researchers [14]. The team of reputable and experienced in these matters N.R. Sottos presented to the public a new concept of «Bio-inspired materials for self-cleaning and self-healing», which demonstrated perspective on self-repair through integrated bio systems and damage-triggering autonomic response [15]. The first «Potential application of self-healing materials in the construction industry» was officially reported by the group of researchers from the Cardiff University, which underlined durability issues relating to cement materials and anticipated a great demand for self-healing concrete [16].

However, Schlumberger is the only petroleum service company so far that devised advanced cement called Futur and applied it to well cementing successfully. Moreover, the role of repair activator in the Futur system hydrocarbons plays. In case of cracks emergence in the cement stone, the first gas shows and after that formation fluid comes, some constituents of hydrocarbons interact with special additives in cement stone, thus within several hours of activation a cement sheath is restored to the original strength and durability. The crack is sealed, no more fluid migration can be detected [17].

The overview of Erin B. Murphy, Fred Wudl then encompassed «The world of smart healable materials». The study presented a deep view of the field of stimuliresponsive healable materials, beginning with a description of the healing of polymeric materials, shortly discussing the regular methodics for mending and maintenance of composite materials [18].

In the Annual review of Material Researches, a group of honoured authors reported a new approach toward safe, long durable class of elastomers and different ways of material coating [19]. From 2010 most of the literature was devoted to the problems of encapsulation and transportation of different healing reagents [20, 21, 22] and inhibitors for corrosion protection [23, 24]. Almost nine years were spent by the Deft University research group working under the control of microbiologist Henk Jonkers, to devise a self-healing concrete, the successful application of which 
was announced in May, 14 2015. The concept is in species of bacillus bacteria incorporation into the concrete. These bacteria are encapsulated in biodegradable plastics that will only burst open when interact with water. After being exposed to water, the bacteria feeds on calcium lactate and produce calcium precipitate, which is homogeneous to cement material thus because of the adhering properties is perfect as cement bonding material [25]. As the author claims, the product will fit best for constructing underground retainers for hazardous waste, but also will faultless serve for tunnel-lining, structural basement walls, highway bridges, concrete floors and marine structures.

Self-healing science accounts almost 35 years of study. However, the biggest breakthrough has been done over less than 15 years. It is explained by the development of new route of engineering and chemical science called nanotechnology, which allowed manipulation atomic structure and size in order to create a new product.

The most fundamental studies were carried out by researchers of USA and Netherlands. The range of healable materials was identified, mechanism of self-healing process, design approaches, transportation of mending agent, encapsulation, triggering mechanism, living environment of healing agents, methods for evaluating selfhealing efficiencies, functional testing conditions all these and many others sides were enlightened.

Self-healing systems found application in various fields. They were successfully adopted by construction engineering. However, this "smart" cement system is a new tendency for petroleum industry, thus requires more detail study of triggering-healing mechanisms. Consequently, there is a sharp relevance of setting the system with special properties in order to ensure the reliable operation in complex reservoir conditions.

\section{The requirements to materials used for self-healing ce- ments production}

The authors of the article set the task of searching for the range of materials most suitable for well cement modification that enables autonomous "healing" of waterconducting channels which appear in the cement stone due to various technological operations. The requirements for the cement modifying additives were set in accordance with the influence of alternating temperatures, high pressures, humidity and periodic dynamic loads to which a cased well is usually exposed.

We believe that they can be formulated as follows:

- the presence of a durable multilayer shell, which should prevent premature swelling of the additive during the cement slurry mixing and injection;

- the activation starts not earlier than after 6 hours after cementing ends;

- the duration of self-healing effect - until the complete stoppage of the water flow;
- the ability to block cracks ranging in size from 50 to 150 microns;

- the continued ability to repeat the activation on the periodic occurrence of the defects;

- no effect on the technological properties of the cement slurry and cement stone.

\section{Objects of the research}

We believe that the water-swellable additive wrapped in a water-soluble coating is firmly fixed in the pores of the cement stone and cannot be washed out by water. When a system of cracks is formed enabling formation water passes through, then the additive is to swell thus filling the entire volume of the cavity and shutting down a crack through which the water filters [26].

The next materials were substantiated and afterwards used in the study: polyacrylamide (PAA), water-swellable polymer (VNP V-615), sodium polyacrylate (SP), crosslinked PAA copolymers, active waterproofing mineral additives and swelling elastomers.

The suitability for water absorbing was substantiated for the each material; the experiments outcomes of the materials swelling kinetics were demonstrated, as well as the resistance to mechanical destruction.

Polyacrylamide (PAA) technical $\left[-\mathrm{CH}_{2} \mathrm{CH}\right.$ $\left.\left(\mathrm{CONH}_{2}\right)-\right] \mathrm{n}$, is a copolymer of polyacrylamide with acrylates at a content of not more than $10 \%$; it is made of acrylonitrile $\mathrm{CH}_{2}=\mathrm{CH}-\mathrm{CN}$, which upon hydrolysis in the presence of sulfuric acid yields acrylamide and partially acrylic acid. Low molecular weight species PAA can be used to as additives for the well sealing and cement stone filtration reduction. High molecular weight species PAA are suitable for creation the elastic and durable film possessing high flocculation ability. There are temperature limitations, since PAA is thermally stable up to $100^{\circ} \mathrm{C}$.

Water-swellable polymer is a single macromolecule sewn from molecular chains. An elastic net is formed by the chains and the bonds between them, which in a dry gel or partially filled with water is twisted and tightly packed in a small volume of grains, for this the osmotic pressure is a water-absorbing mechanism. The particle size of WSP granules - no more than $2 \mathrm{~mm}$, density ranges from 1150 to $1200 \mathrm{~kg} / \mathrm{m}^{3}$. Powdered WSP swells in fresh water increasing in the volume by $80-100$ times, and in formation water (with mineralization of 150 gram per liter and more) - by 50-60 times. The process of swelling and WSP expansion does not depend on the pressure applied to it; it is also resistant to the influence of temperature (up to $170^{\circ} \mathrm{C}$ ).

Sodium polyacrylate $(\mathrm{SP})$ is a sodium salt of polyacrylic acid with the chemical formula $\left[-\mathrm{CH}_{2-} \mathrm{CH}(\mathrm{COONa})-\right] n$ and is an anionic polyelectrolyte with a negatively charged carboxyl group in the main chain. One of the main prop- 
erties of the compound is the ability to absorb liquids 200-300 times its weight. Sodium polyacrylate is well soluble in water; it easily swells, and therefore is a good thickener and gelling agent.

Waterproofing mineral additives (WMA) can also be used for the cement stone sealing restoration. WMA's pozzolanic activity is determined by the presence of amorphous silica in the composition, which interacts with $\mathrm{Ca}(\mathrm{OH})_{2}$, forming highly dispersed calcium hydrosilicates with enhanced binding properties, which contributes to both increasing the strength of the stone and reducing the size of pores, as well as reduces the cement stone permeability. Acid ashes act in the same way, the pozzolanic reaction of which begins at the age of concrete of 7-14 days, and most of the reaction takes place within 30 and 90 days [28].

Highly dispersed WMA, such as silica fume, metakaolin most actively interacts with lime at an early age of 3 days. The high chemical activity of silica fume leads to the fact that, according to some data, 25-30\% silica fume by cement mass can completely bind $\mathrm{Ca}(\mathrm{OH})_{2}$ in the cement stone, whereas $60 \%$ ash by cement mass approximately 3-4\% lime remains in the free state.

Water swellable elastomers are rubbers and rubber compounds, which operate on the principle of osmosis, the water is drawn into the elastomer and after retained therein due to differential salinity across the elastomer surface [29]. Swelling elastomers-polymers have highly elastic properties, - by adjusting the recipe of elastomer compositions, the dynamics of swelling in a particular medium can be set (up to $400 \%$ or more), - the swelling rate, the operating temperature, the physical and mechanical requirements of the product, etc.
Cross-linked copolymer $\boldsymbol{A A}$ is a superabsorbent based on anionic polyacrylamide. It is a water-insoluble crosslinked copolymer of acrylamide and potassium acrylate. The polymers contain a set of polymer chains parallel to each other. They are regularly connected by crosslinking agents, forming a grid. When water contacts one of these chains, it is drawn into the polymer molecule by osmosis. Thus, water is stored, quickly migrating into the polymer network. The cross-linked AA copolymer absorbs the amount of water up to 500 times its mass, turning into gels.

\section{CONCLUSION}

Thereby, the performed studies have shown:

- the cement stone in oil and gas wells is known to be the most vulnerable element of the lining, which can be easily destructed during technological operations carrying out inside the well, and there is almost the only way to restore the cement stone integrity which is in the usage of "self-healing" cement;

- analysis of foreign experience in the elaboration and application of self-healing materials demonstrated the high efficiency in various industries, as well as showed a possibility of the successful application for oil and gas wells cementing;

- requirements for materials which can be used as modifying additives for self-healing cements were substantiated;

- various types of polymeric materials were substantiated and analyzed, and it was shown the crosslinked copolymer AA, which is superabsorbent based on anionic polyacrylamide, meets the most requirements.

\section{ВВЕДЕНИЕ}

И стория эксплуатации разновозрастных скважин показывает, что цементный камень является наиболее уязвимым звеном и способен легко разрушаться под действием динамических нагрузок и давлений, действующих изнутри обсадной колонны, от воздействия агрессивных пластовых флюидов, действующих со стороны горных пород [1]. Однако существует возможность сохранения целостности крепи скважины при соответствующей модификации цементов. Задачу по улучшению качества цементного камня с использованием специальных добавок, способного эффективно герметизировать пространство между стенкой скважины и обсадной колонны, а также устранять каналообразование до момента образования системы трещин и заколонной циркуляции воды (ЗКЦ), ставят перед собой многие российские и иностранные ученые. Одним из перспективных решений указанной задачи является применение «самозалечивающихся» цементов.

\section{ОСНОВНАЯ ЧАСТЬ}

\section{Исторический обзор}

Концепция самовосстанавливающихся полимерных материалов известна с 1980-х гг. В 1981-м году Дональд Джуд в своей работе отразил возможность исцеления невидимых микротрещин с целью продления срока службы полимерных компонентов [2]. 
Первыми статьями, которые продемонстрировали способность ряда полимерных материалов «самозалечивать» трещину, были «Пассивное умное самовосстановление в полимерных матричных композиционных материалах», опубликованная в Вирджинии, США [3], и «Автономное исцеление полимерных композитов» [4], где были обнародованы успешные попытки оценить закономерность разрастания трешины в полимерных материалах и их восстановление. В 2003 году группа исследователей из разных американских университетов продемонстрировала самовосстанавливающийся армированный волокнами структурный полимер, который представлял собой матричный композитный материал с микрокапсулированным химическим катализатором, подвергавшийся трещинообразованию при комнатной температуре [5]. С тех пор многократно возрос интерес, связанный с поиском материалов и исследованием механизма самовосстановления, притянув внимание различных стратегически важных организаций - от архитектурных агентств, гражданского строительства до ВВС США [6] и Европейского космического агентства [7], которые вложили значительные средства для проведения исследований самовосстанавливающихся полимеров.

Первый обзор широкого спектра самовосстанавливающихся материалов был написан профессором Делфтского технического университета, доктором Сибранд ван дер Цваагом, который описал категории, различные подходы к разработке и фактические строительные способности таких материалов, как керамика, полимеры и металлы [8]. Наиболее убедительные исследования, связанные с явлением самовосстановления материалов, были продемонстрированы Делфтским техническим университетом во время проведения в 2007 году «Первой международной конференции по самовосстанавливающимся материалам», проходившей в Нидерландах. В то же время группа американских исследователей разработала концепцию эффективного размера частиц инкапсулированных самовосстанавливающихся полимеров, которые были соразмерны максимально возможному размеру трещины, таким образом, результат исследований продемонстрировал достижение желаемого восстановительного эффекта [9].

В журнале «Химия материалов», опубликованном в 2008 году, доктор Шеба Д. Бергман и профессор Фред Вудл, основываясь на свойстве обратимости, полностью описали способность полимеров к восстановлению [10]. Те же результаты были подтверждены и дополнены исследовательской группой из Университета Варвика, которая более детально изучила явление самовосстановления в полимерах [11]. Профессор Ричард П. Вул внес вклад в материаловедение, описав механическое и термическое повреждение и заживление полимеров [12]. Команда Д.И. Ву в своей статье описала механизм разрушения и концепцию заживления в полимерных системах, а также предложила методы оценки эффективности самовосстановления [13]. Полный спектр применения самовосстанавливающих способностей материалов был обобщен в работах китайских исследователей [14]. Команда авторитетных и опытных исследователей под руководством Н.Р. Соттоса представила общественности новую концепцию «Биоинспирированных материалов для самоочищения и самовосстановления», которая продемонстрировала перспективу самовосстановления с помощью интегрированных биосистем и автономного реагирования на повреждения [15]. Первое «Потенциальное применение самовосстанавливающихся материалов в строительной отрасли» было официально опубликовано группой исследователей из Университета Кардиффа, которая вынесла проблемы долговечности цементных материалов и предсказала высокий спрос на самовосстанавливающиеся бетоны [16].

Однако на сегодняшний день компания Шлюмберже является единственной нефтесервисной компанией, разработавшей и успешно применяющей «самозалечивающийся» цемент Futur, который активно применяется для цементирования скважин. Кроме того, роль триггерного механизма для активации цементной системы Futur выполняют углеводородные газы. Таким образом, при появлении трещин в цементном камне, некоторые компоненты проникнувшего углеводородного газа вступают в контакт со специальными добавками, интегрированными при затворении цемента, после их взаимодействия ранее поврежденный цементный камень восстанавливается до первоначального вида, сохраняя исходную прочность. Цементное кольцо герметизируется в течение нескольких часов, после чего миграции жидкости не происходит [17].

Обзор Эрин Б. Мерфи и Фреда Вудла охватил «Мир умных исцеляющих материалов». В их исследовании представлен глубокий взгляд на область самовосстанавливающихся материалов, представлены некоторые активаторные механизмы и способы залечивания каналов, вкратце обсуждается долговечность и многократность использования композитных материалов [18].

$\mathrm{B}$ «Ежегодном обзоре исследований новых материалов» группа авторитетных авторов сообщила о новом подходе к разработке безопасного, долговечного класса эластомеров, а также о различных способах нанесения покрытий на материалы [19]. С 2010 года значительный объем исследований был посвящен проблемам инкапсуляции и транспортировки различных самозалечивающих агентов [20, 21, 22], а также ингибиторов для защиты от коррозии [23, 24]. 
Почти девять лет группой ученых из Делфтского технического университета под руководством микробиолога профессора Хенка Джонкерса проводились исследования и разработка самовосстанавливающегося бетона, успешное применение которого было объявлено 14 мая 2015 года. Концепция данной разработки заключалась в введении особенного вида бактерий бацилл в состав строительного бетона и обеспечении им питательной среды. Эти бактерии были заключены в биоразлагаемый пластик, который разлагался при взаимодействии с водой. После того, как капсулы с бактериями подвергались воздействию воды, бактерии начинали питаться лактатом кальция и производить отложения кальция, которые в свою очередь являются гомогенными по отношению к цементному материалу, демонстрируя идеальную адгезию к последнему. Соответственно, прочно сцепляясь с базовым материалом, продукт жизнедеятельности бацилл перекрывал канал, тем самым блокируя путь миграции газа [25]. Как утверждает автор разработки, его продукт лучше всего подходит для строительства подземных хранилищ опасных отходов, а также для прокладки подземных туннелей, фундаментов, автодорожных мостов, бетонных перекрытий и гидротехнических сооружений.

Наука, изучающая материалы и механизмы самовосстановления, существует уже более 35 лет, однако самый большой прорыв был сделан менее чем за 15 лет. Это объясняется развитием нового направления инженерной и химической наук, название которому нанотехнология, которое дает возможность работать со структурой атома и, подвергая его различным манипуляциям, создавать новый продукт.

Так, основополагающие исследования были проведены учеными из США и Нидерландов. Американцами был определен спектр материалов, демонстрирующих способности к самовосстановлению; изучен механизм автономного самозалечивания. Голландцами разработаны способы инкапсулирования самозалечивающих агентов, их транспортировка до места назначения, триггерные механизмы, среды обитания самозалечивающих агентов, методы оценки эффективности самовосстановления, условия для тестирования их функциональной пригодности и мн. др.

Самовосстанавливающиеся системы нашли свое применение в различных областях, особенно были успешно применены в промышленном строительстве. Однако подобная «умная» цементная система является новой тенденцией для нефтяной промышленности, поэтому требует более детального изучения механизмов активации и восстановления. В том числе требуется задание системе специальных свойств, обеспечивающих ее надежное функционирование в сложных пластовых условиях.
Требования к материалам для получения самозалечивающихся цементов

Авторами данной статьи ставилась задача по определению спектра материалов, наиболее пригодных для модифицирования тампонажных цементов для придания им способностей к автономному «залечиванию» водопроводящих каналов, появляющихся в цементном камне внутри скважины в процессе проведения различных технологических операций. Исходя из воздействия знакопеременных температур, высоких давлений, влажности и периодических динамических нагрузок, приходящихся на крепь скважины, были определены требования к свойствам добавок, используемых для модификации цементов, применяемых при креплении.

Мы полагаем, что их можно сформулировать следующим образом:

- наличие прочной многослойной оболочки, которая должна предотвратить преждевременное набухание добавки на этапе приготовления и закачки цементных растворов;

- начало активации водопоглощения не ранее, чем через 6 часов после окончания цементирования;

- длительность эффекта самозалечивания - до полного прекращения поступления воды;

- способность перекрывать трещины размером от 50 до 150 мкм;

- сохранение способности многократного действия на периодическое возникновение дефектов;

- отсутствие влияния на технологические свойства тампонажного раствора и цементного камня.

\section{Объекты исследования}

Мы полагаем, что, находясь в порах цементного камня, водонабухающая добавка, обернутая водорастворимой оболочкой, жестко закрепляется в порах и не вымывается водой. При образовании системы трещин и поступлении пластовой воды добавка должна набухать, заполняя весь объем полости, что не позволит воде фильтроваться через цементный камень [26].

Для проведения исследований обоснованы и выбраны следующие материалы: полиакриламид (ПАА), водонабухающий полимер (ВНП В-615), полиакрилат натрия (ПАН), сшитые сополимеры ПАА, активные гидроизолирующие минеральные добавки и набухающие эластомеры.

Для каждого материала обоснована его пригодность в качестве водопоглотителя, также представлены результаты экспериментов по определению кинетики набухания материалов и стойкости механическому разрушению.

Полиакриламид (ПАА) технический $\left[-\mathrm{CH}_{2} \mathrm{CH}\right.$ $\left.\left(\mathrm{CONH}_{2}\right)-\right] \mathrm{n}$, представляет собой сополимер поли- 
акриламида с акрилатами при содержании последних не более $10 \%$, производится из нитрила акриловой кислоты $\mathrm{CH}_{2}=\mathrm{CH}-\mathrm{CN}$, который при гидролизе в присутствии серной кислоты дает акриламид и частично акриловую кислоту. Низкомолекулярные разновидности ПАА могут быть использованы для создания добавок с целью герметизации и снижения фильтрации цементного камня, высокомолекулярные разновидности ПАА подходят для создания эластичной и прочной пленки с высокой флокулирующей способностью. Существуют температурные ограничения, поскольку ПАА термически устойчив до $100^{\circ} \mathrm{C}$.

Водонабухающий полимер представляет собой единые макромолекулы, сшитые из молекулярных цепочек. Цепочки и связи между ними образуют упругую сетку, которая в сухом геле или частично наполненном водой скручена и плотно упакована в небольшом объеме крупинок, для которых осмотическое давление является водопоглотительным механизмом. Размер частиц гранул ВНП - не более 2 мм, плотность от 1150 до 1200 кг/м³. Порошкообразный ВНП набухает во времени в пресной воде в 80-100 раз, а в пластовой воде (с минерализацией 150 г/литр и больше) - в 50-60 раз по объему. Процесс набухания и расширения ВНП не зависит от давления на него, также он стоек к воздействию температуры (до $170^{\circ} \mathrm{C}$ ).

Полиакрилат натрия - натриевая соль полиакриловой кислоты, имеет химическую формулу вида $\left[-\mathrm{CH}_{2-} \mathrm{CH}(\mathrm{COONa})-\right] n$ и представляет собой анионный полиэлектролит с отрицательно заряженной карбоксильной группой в основной цепи. Одним из основных свойств соединения является способность абсорбирования жидкости в 200-300 раз больше собственного веса. ПАН хорошо растворяются в воде, при этом легко набухают, поэтому являются хорошими загустителями и гелеобразователями.

Гидроизолирующие минеральные добавки (ГМД) также можно применять для восстановления герметичности цементного камня. Пуццолановая активность ГМД определяется присутствием в их составе аморфного кремнезема, который взаимодействует с $\mathrm{Ca}(\mathrm{OH})_{2}$, образуя высокодисперсные гидросиликаты кальция с повышенными вяжущими свойствами, что способствует как увеличению прочности камня, так и уменьшению размеров пор, что снижает проницаемость цементного камня. Такой активностью обладают, например, кислые золы, пуццолановая реакция которых начинается в возрасте бетона 7-14 суток, а основная ее часть протекает в период 30-90 дней [28].

Высокодисперсные ГМД, такие как микрокремнезем, метакаолин наиболее активно взаимодействуют с известью в раннем возрасте, начиная с 3 суток.
Высокая химическая активность микрокремнезема приводит к тому, что, по некоторым данным, 25$30 \%$ его от массы цемента могут полностью связать $\mathrm{Ca}(\mathrm{OH})_{2}$ в цементном камне, тогда как при $60 \%$ золы примерно 3-4\% его остается в свободном состоянии.

Водонабухающие эластомеры - это каучуки и резиновые смеси, которые работают по принципу осмоса, и вода втягивается в эластомер и удерживается в нем из-за перепада солености поперек поверхности эластомера [29]. Набухающие эластомеры-полимеры обладают высокоэластическими свойствами. Регулируя рецепт эластомерных композиций, можно задавать динамику набухания в конкретной среде (до 400\% и более), скорость набухания, температуру эксплуатации, физико-механические требования изделия и т.д.

Cиитый сополимер $\boldsymbol{A} \boldsymbol{A}$ - суперабсорбент на основе анионного поликриламида. Он представляет собой нерастворимые в воде сшитые сополимеры акриламида и акрилата калия. Полимеры содержат набор полимерных цепочек, параллельных друг другу. Они регулярно соединены сшивающими агентами, образуя сетку. Когда вода контактирует с одной из этих цепочек, она втягивается в молекулу полимера благодаря осмосу и сохраняется, быстро мигрируя внутрь полимерной сетки. Сшитый сополимер АА абсорбирует количество воды до 500 раз больше своей массы, переходя в гели.

\section{ЗАКЛЮЧЕНИЕ}

Таким образом, выполненные исследования показали:

- цементный камень в нефтяных и газовых скважинах, являясь наиболее уязвимым элементом крепи, легко разрушается при проведении технологических операций внутри скважины, и практически единственным способом восстановления его герметичности является применение самозалечивающихся цементов;

- анализ зарубежного опыта разработки и применения самовосстанавливающихся (самозалечивающихся) материалов, имеющих высокую эффективность в различных отраслях промышленности, показал, что они не могут использоваться при креплении нефтяных и газовых скважин;

- обоснованы требования к материалам, которые могут быть использованы в качестве модифицирующих добавок к самозалечивающимся цементам;

- обоснованы и проанализированы различные виды полимерных материалов и показано, что в наибольшей степени предъявляемым требованиям отвечает сшитый сополимер АА, являющийся суперабсорбентом на основе анионного поликриламида. 


\section{REFERENCES}

1. Agzamov F.A., Izmuhambetov B.S. Dolgovechnost' tamponazhnogo kamnya v korrozionno-aktivnyh sredah [Oil well stone durability in corrosive environments]. Saint-Petersburg. 2005. 317 p. (In Russian).

2. Donald Jud G. and James M. Watts. Land Economics. 1981. Vol. 57, issue 3. P. 459-470.

3. Dry, C. and Sottos, N.R. Passive smart self-repair in polymer matrix composites. In Smart Structures. 1993: Smart Materials, V.K. Varadan, ed., Vol. SPIE 1916. P. 438-444.

4. White, S.R. et al. Autonomic healing of polymer composites. Nature. 2001 - 409(6822). P. 794-797.

5. Kessler, M.R., Sottos, N.R. \& White, S.R. Self-healing structural composite materials. Composites Part A: Applied Science and Manufacturing. 2003. 34(8). P.743-753.

6. Carlson, H.C. \& Goretta, K.C., Basic materials research programs at the U.S. Air Force Office of Scientific Research. Materials Science and Engineering B: Solid-State Materials for Advanced Technology. 2006. 132(1-2). P. 2-7.

7. Semprimosching C. Enabling self-healing capabilities - a small step to bio-mimetic materials. European Apace Agency Materials Report Number. 2006. 4476.

8. S. van der Zwaag. Self-Healing Materials: an Alternative Approach to 20 Centuries of Materials Science. Springer. 2007.387 p.

9. Rule, J.D., Sottos, N.R. \& White, S.R., Effect of microcapsule size on the performance of self-healing polymers. Polymer. 2007. 48(12). P. 3520-3529.

10. Bergman, S.D. \& Wudl, F. Mendable polymers. Journal of Materials Chemistry. 2008. 18(1), P. 41.

11. Syrett, J.A., Becer, C.R. \& Haddleton, D.M. Self-healing and self-mendable polymers. 2010. P. 978-987.

12. Wool, R.P. Self-healing materials. A review. Soft Matter. 2008. Vol. 4(3). P. 400.

13. Wu, D.Y., Meure, S. \& Solomon, D. Self-healing polymeric materials: A review of recent developments. Progress in Polymer Science. 2008. 33(5). P. 479-522.

14. Yuan, Y.C. et al., Self healing in polymers and polymer composites. Concepts, realization and outlook: A review. Express Polymer Letters. 2008. 2(4). P. 238-250.

15. Youngblood J.P. \& Sottos N.R. Bioinspired Materials for Self-Cleaning and Self-Healing. MRS Bulletin. 2008. 33(08). P. $732-741$.

16. Joseph, C. \& Lark, R., Potential application of self-healing materials in the construction industry A report for the Institution of Civil Engineers Tony Jefferson and Diane Gardner. Construction. 2009. (June).

17. Nelson E. Cement Chemistry and Additives. Schlumberger OilField Review. 2008. P. 18-25

18. MurphyE.B. \& Wudl F. The world of smart healable materials. Progress in Polymer Science (Oxford). 2010. 35(1-2). P. 223-251.

19. Blaiszik B. \& Kramer, S., Self-healing polymers and composites: Supplimental. Annual Review of Materials Research. 2010. P. 1-4.

20. Szabó, T. et al. Self-healing microcapsules and slow release microspheres in paints. Progress in Organic Coatings. 2011. 72(1-2). P. 52-57.

21. Zhao, Y. et al. Self-healing coatings containing microcapsule. Applied Surface Science. 2012. 258(6). P. $1915-1918$.

22. Blaiszik, B.J. et al. Microencapsulation of gallium-indium (Ga-In) liquid metal for self-healing applications. Journal of microencapsulation. 2014. 2048. P.2013-2014.

23. Zhao, Y. et al. The self-healing composite anticorrosion coating. Physics Procedia. 2011. Vol. 18. P. $216-221$.

24. Montemor, M.F. Functional and smart coatings for corrosion protection: A review of recent advances. Surface and Coatings Technology. 2014. 258. P. 17-37.

25. Jonkers, H., Self-Healing Concrete by Bacterial Mineral Precipitation. 2015.

26. Ismagilova E.R., Agzamov F.A. Razrabotka dobavok v «samozalechivayushchiesya» cementy dlya vosstanovleniya germetichnosti cementnogo kol'ca neftyanyh i gazovyh skvazhin [Development of additives in "self-healing" cements to restore the cement stone integrity in oil and gas wells]. Burenie i Neft' [Drilling and Oil]. Moscow. 2016. № 5. P. 24-29. (In Russian).

27. Ismagilova E.R., Agzamov F.A., Abbas A.J. Optimization of self-healing additives dispersity in cement. Georesursy = Georesources. 2017. V. 19. No. 2. P. 129-134. DOI: http://doi.org/10.18599/grs.19.2.7.

28. ZotkinA.G. Betony s effektivnymi dobavkami [Concrete with effective additives]. Teaching manual. Moscow. InfraEngineering, 2014. 160 p. (In Russian).

29. Shahmin A.M. Nabuhayushchie elastomernye pakery [Swelling elastomer packers]. Molodaya neft': sb. statej. Vseros. molodezhnoj nauch.-tekhn. konf. neftegazovoj otrasli. [Young Oil: Sat. articles. All-Russia. youth science-tech. conf. oil and gas industry]. Krasnoyarsk: Sib. Feder. Univ, 2014. (In Russian).

\section{СПИСОК ЛИТЕРАТУРЫ}

1. Агзамов Ф.А., Измухамбетов Б.С. Долговечность тампонажного камня в коррозионно-активных средах. - СПб. 2005. -317 c.

2. Donald Jud G. and James M. Watts. Land Economics. - 1981. - vol. 57, issue 3. - P. 459-470.

3. Dry C. and Sottos N. R. Passive smart self-repair in polymer matrix composites. In Smart Structures. - 1993: Smart Materials, V.K. Varadan, ed., vol. SPIE 1916. - P. 438-444.

4. White, S.R. et al. Autonomic healing of polymer composites // Nature. - 2001. - 409(6822). - P. 794-797. 
5. Kessler, M.R., Sottos, N.R. \& White, S.R. Self-healing structural composite materials. // Composites Part A: Applied Science and Manufacturing. - 2003. - 34(8). - P. 743-753.

6. Carlson, H.C. \& Goretta, K.C., Basic materials research programs at the U.S. Air Force Office of Scientific Research // Materials Science and Engineering B: Solid-State Materials for Advanced Technology. - 2006. - 132(1-2). - P. 2-7.

7. Semprimosching C. Enabling self-healing capabilities - a small step to bio-mimetic materials. // European Apace Agency Materials Report Number. - 2006. - 4476.

8. S. van der Zwaag. Self-Healing Materials: an Alternative Approach to 20 Centuries of Materials Science. Springer. - 2007. - 387 p.

9. Rule, J.D., Sottos, N.R. \& White, S.R., Effect of microcapsule size on the performance of self-healing polymers // Polymer. 2007. - 48(12). - P. 3520-3529.

10. Bergman, S.D. \& Wudl, F. Mendable polymers. // Journal of Materials Chemistry. - 2008. - 18(1), P. 41.

11. Syrett, J. a., Becer, C.R. \& Haddleton, D.M. Self-healing and self-mendable polymers. - 2010. - P. 978-987.

12. Wool, R.P. Self-healing materials. a review // Soft Matter. - 2008. - Vol. 4(3). - P. 400.

13. Wu, D.Y., Meure, S. \& Solomon, D. Self-healing polymeric materials: A review of recent developments. // Progress in Polymer Science. - 2008. - 33(5). - P. 479-522.

14. Yuan, Y.C. et al., Self healing in polymers and polymer composites. Concepts, realization and outlook: A review. Express Polymer Letters. - 2008. - 2(4). - P. 238-250.

15. Youngblood J.P. \& Sottos N.R. Bioinspired Materials for Self-Cleaning and Self-Healing // MRS Bulletin. - 2008. 33(08). - P.732-741.

16. Joseph, C. \& Lark, R. Potential application of self-healing materials in the construction industry A report for the Institution of Civil Engineers Tony Jefferson and Diane Gardner. Construction. - 2009. - (June).

17. Nelson E. Cement Chemistry and Additives // Schlumberger OilField Review. - 2008. - P.18-25.

18. MurphyE.B. \& Wudl F. The world of smart healable materials // Progress in Polymer Science (Oxford). - 2010. - 35(1-2). P. 223-251.

19. Blaiszik B. \& Kramer S. Self-healing polymers and composites: Supplimental // Annual Review of Materials Research. 2010. - P. 1-4.

20. Szabó, T. et al. Self-healing microcapsules and slow release microspheres in paints // Progress in Organic Coatings. 2011. - 72(1-2). - P. 52-57.

21. Zhao, Y. et al. Self-healing coatings containing microcapsule // Applied Surface Science. - 2012. - 258(6). - P. $1915-1918$.

22. Blaiszik, B.J. et al. Microencapsulation of gallium-indium (Ga-In) liquid metal for self-healing applications. // Journal of microencapsulation. - 2014. - 2048. - P. 2013-2014.

23. Zhao, Y. et al. The self-healing composite anticorrosion coating // Physics Procedia. - 2011. - Vol. 18. - P. $216-221$.

24. Montemor, M.F. Functional and smart coatings for corrosion protection: A review of recent advances // Surface and Coatings Technology. - 2014. - 258. - P. 17-37.

25. Jonkers, H., Self-Healing Concrete by Bacterial Mineral Precipitation. 2015.

26. Исмагилова Э.Р., Агзамов Ф.А. Разработка добавок в «самозалечивающиеся» цементы для восстановления герметичности цементного кольца нефтяных и газовых скважин // Бурение и Нефть. - 2016. - № 5. - С. 24-29.

27. Исмагилова Э.Р., Агзамов Ф.А., Аббас А.Д. Оптимизация дисперсности добавок в самозалечивающихся цементах // Георесурсы. - 2017. - Т. 19, № 2. - С. 129-134.

28. Зоткин А.Г. Бетоны с эффективными добавками. - М.: Инфра-Инженерия, 2014. - 160 с.

29. Шахмин А.М. Набухающие эластомерные пакеры // Молодая нефть: сб. статей. Всерос. молодежной науч.-техн. конф. нефтегазовой отрасли. - Красноярск: Сиб. федер. ун-т, 2014.

\section{INFORMATION ABOUT THE AUTHORS}

Farit A. Agzamov, Doctor of science, Professor of the Department «Oil and Gas Well Drilling», Ufa State Petroleum Technological University; Kosmonavtov st. 1, Ufa, Russia, 450062, faritag@yandex.ru;

Elvira R. Ismagilova, MSc (UK, University of Salford)), PhD student of Professor of the Department «Oil and Gas Well Drilling», Ufa State Petroleum Technological University; Kosmonavtov st. 1, Ufa, Russia, 450062, yusupova_elvira@mail.ru

\section{ИНФОРМАЦИЯ ОБ АВТОРАХ}

Агзамов Фарит Акрамович, д.т.н., проф., профессор кафедры «Бурение нефтяных и газовых скважин» ФГБОУ ВО «УГНТУ»; ул. Космонавтов 1, г. Уфа, Россия, 450062, faritag@yandex.ru;

Исмагилова Эльвира Римовна, магистр нефтегазового дела (Великобритания, Университет Сэлфорда), аспирант кафедры «Бурения нефтяных и газовых скважин» ФГБОУ ВО «УГНТУ»; ул. Космонавтов 1, г. Уфа, Россия, 450062, yusupova_elvira@mail.ru 